\title{
Aquila's Greek Targum: Reconsidering the Rabbinical Setting of an Ancient Translation
}

\author{
Anthony Giambrone \\ École biblique de Jérusalem
}

\section{Introduction}

Aquila of Sinope, the legendary second-century translator and convert to Judaism, appears in both Jewish and Christian tradition. Recent literature on his famous Greek translation of the Hebrew Scriptures is surprisingly limited, however. ${ }^{1}$ Dominique Barthélemy's landmark monograph on the Minor Prophets' scroll gives some significant introductory attention to Aquila and the influence of Rabbi Akiva upon him, but the study's influential (if traditional) conclusions cannot be considered final. ${ }^{2}$ Lester Grabbe, in particular, has critiqued Barthélemy's portrayal of Aquila as a zealous follower ("un chaud partisan") of Akiva and of his characteristic manner

\footnotetext{
${ }^{1}$ The bibliography is rather short, and many of the available studies date from the $19^{\text {th }}$ cent. See especially Meir Friedmann, Onkelos und Akylas (Wien: Lippe, 1896); and Samuel Krauss, "Akylas, der Proselyt," in Festschrift zum achtzigsten Geburtstage Moritz Steinschneider's (Leipzig: Harrassowitz, 1896) 148-63. See also Frederick Field, Originis Hexaplorum quae supersunt sive veterum interpretum graecorum in totum vetus testamentum fragmenta, I-II (Oxford, 1875; reprinted, Hildesheim: Georg Olms Verlagsbuchhandlung, 1964) xv-xxviii. For a complete listing of the introductory literature, see Giuseppe Veltri, Libraries, Translations, and 'Canonic' Texts: The Septuagint, Aquila and Ben Sira in the Jewish and Christian Traditions (JSJSup 109; Leiden: Brill, 2006) 164 n. 42.

${ }^{2}$ Dominique Barthélemy, Les devanciers d'Aquila (VTSup 10; Leiden: Brill, 1963). Barthélemy built his work around the traditional scholarly impression, generated by the rabbinic literature, that Aquila's translation was closely connected to Rabbi Akiva's exegetical school. "On sait déjà que les principes sur lesquels Aquila a fondé sa recension de la Bible grecque dependent étroitement de l'herménuetique d'Aquiba," 3.
}

HTR 110:1 (2017) 24-45 
of exegesis (especially the inclusive sense he gave the accusative particle 'êt). ${ }^{3}$ If there are real reasons informing this conventional depiction of Aquila, for Grabbe, "no isolated theory linking a particular translation with a particular figure of Jewish literature can truly claim serious attention," without considerably more information about how the whole spectrum of Greek recensional activity interacted with all the diverse forms of ancient Jewish interpretation. ${ }^{4}$ Grabbe offers an important critique. At the same time, he requires a considerable advance in our knowledge. Indeed, given many irremediable uncertainties touching the precise information Grabbe would demand, it is not clear how far conclusions in this area can ever be entirely distanced from conjectures.

If a more sophisticated analysis is in fact required, scholarship has nonetheless moved away from focused textual studies like that of Barthélemy. ${ }^{5}$ The present mood has rather been to highlight the embarrassing negative judgments that have plagued descriptions of Aquila's “wooden" translation. Tessa Rajak, for instance, logs examples of "the persistent stereotype of the clever and obstinate Jew." "Given the patristic pedigree of this stereotype, it is not surprising to find Jenny Labendz's attempted reappraisal of the Aquila tradition dramatically opposing Christian and Jewish sources. ${ }^{7}$ Labendz's effort to sift out pure rabbinic testimony about Aquila from distinctly Christian traditions has exposed our conflated picture, yet it ends in

\footnotetext{
${ }^{3}$ Akiva taught that the direct object marker ' $\bar{t} t$ might be taken as the identically-spelled preposition meaning "with" (see Gen. Rab. 1.14). This is reflected in Aquila's celebrated rendering of Gen 1:1:

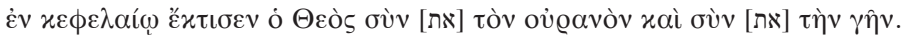

${ }^{4}$ Lester Grabbe, “Aquila’s Translation and Rabbinic Exegesis,” JJS 33 (1982) 527-36, at 536. See also the doubts expressed by James Barr in his review of Barthélemy's Les devanciers (JJS 11 [1966] 263); and the argument of André Paul, "La Bible grec d'Aquila et l'idéologie du judaïsm ancien," ANRW 20:1 (1983) 221-45.

${ }^{5}$ Perhaps it is more accurate to say textual studies have lost the broader implications and wide influence enjoyed by Barthélemy's project. The field has not dried up: see, e.g., Peter Gentry, "The Relationship of Aquila and Theodotion to the Old Greek of Ecclesiastes in the Marginal Notes of the Syro-Hexapla," Aramaic Studies 2 (2004) 63-84; and Johann Lust, "A Lexicon of the Three and the Transliterations in Ezekiel," in Origen's Hexapla and Fragments (ed. A. Salvesen; Tübingen: Mohr Siebeck, 1998) 274-301. The recent republication and translation of Frederick Field's important work on the Hexapla is an encouraging sign. See Gérard Norton, Frederick Field's Prolegomena to Origenis Hexaplorum quae supersunt, sive veterum interpretum graecorum in totum vetus testamentum fragmenta (Cahiers de la Review Biblique 62; Paris: Gabalda, 2005).

${ }^{6}$ Tessa Rajak, Translation and Survival: The Greek Bible of the Ancient Jewish Diaspora (Oxford: Oxford University Press, 2009) 293. The influence of Naomi Seidman (Faithful Renderings: JewishChristian Difference and the Politics of Translation [Chicago: University of Chicago Press, 2006]) can be felt in several recent studies. For a dispassionate review of the ancient stereotype and its basis, as well as a record of the more laudatory comments of Origen and Jerome, see the fair and informative treatment of Joseph Reider, Prolegomena to a Greek-Hebrew and Hebrew-Greek Index to Aquila (Philadelphia: Oxford University Press, 1916) 16-36.

${ }^{7}$ Jenny Labendz, “Aquila's Bible Translation in Late Antiquity: Jewish and Christian Perspectives," HTR 132 (2009) 353-88.
} 
a rather strange result. It is no longer, as with Grabbe, Aquila's connection to Akiva that requires re-evaluation; it is Aquila's connection to the rabbinic movement itself. Specifically, Aquila is considered largely an outsider, even in the rabbinic texts. ${ }^{8}$

Labendz's severe assessment reflects real difficulties in the study of this figure, who is often lost in a fog of legend. Still, her attention is on the portrayal of Aquila in rabbinic literature, not the history behind it; and here she has construed the evidence in a dubious way. The historical implications of her work, accordingly, exceed the caution urged by Grabbe's critique, and such skepticism is enabled by her truncated methodology. Accordingly, in this paper I will attempt to reconsider the rabbinic evidence Labendz has advanced, with greater openness to the non-rabbinic sources. This requires risking guesses, where she is reluctant to speculate. Even so, I hope to present an alternative picture of Aquila's integration into rabbinic society - at least as plausible as the minimalistic suggestion of Labendz's hyper-cautious approach.

Against the revisionist vision, I will thus specifically argue that Aquila was accepted as a mĕturgĕmān responsible for a complete, written translation of the Torah, valued and consulted - and indeed further developed-within rabbinic circles. Following the patristic testimony, moreover, accepted by earlier scholars such as Frederick Field and Saul Lieberman, I find it illuminating to accept the hypothesis that two "editions" of this translation were produced. This at once answers an objection raised by Labendz and also helps foster a more robust understanding of the dynamics animating the development of targumic activity in Greek.

While the first edition of Aquila's translation seems to represent a more conventional targumic relationship to the Hebrew text and probably stands closer to the "historical" Aquila, the second was a revision executed on different principles, related to the wider movement of Greek recensions, as Barthélemy rightly understood. This second edition, I propose, allows the traditional core connection of Aquila's work to Akivan exegesis to be affirmed. Rather than insisting upon a close personal relationship between the two historical figures, however, as Barthélemy still did, it is best to imagine intersecting (eponymous) schools of activity: an "Aquilan" tradition of translational work, closely interacting with an "Akivan" school of interpretation. This answers sufficiently the legitimate concerns raised by Grabbe, within the constraints of our limited knowledge.

\section{Aquila and the Rabbinic Movement}

Labendz has called into question traditional views on the project of Aquila the proselyte. Against a large number of scholars, she points to the incomplete evidence in the sources and warns that no rabbinic endorsement of a written Greek Bible is

${ }^{8}$ Ibid., 387. 
anywhere explicitly recorded. Instead, she argues for an ad hoc activity supplying sages with "atomistic translations of difficult texts." ${ }^{\text {A }}$ As near as we can tell, Aquila was simply a resource in difficult cases: "a dictionary of sorts." 10

On the one hand, Labendz is right to recognize Aquila's liminal status. While "in some respects he was perceived as an insider in rabbinic culture," it is true he is never perfectly integrated into the company of the sages, nor is he normally portrayed practicing developed forms of midrash. ${ }^{11}$ On the other hand, Labendz has overplayed this marginal status. As a proselyte it is inescapable that Aquila be something of an outsider. Yet it is noteworthy that the sages openly downplay this issue. To the extent that the person and his function are separable, the literature offers parallel stories of Aquila's approbation: Rabbi Eliezer and Rabbi Joshua jointly confirm him both as a convert and as a mĕturgĕmān.

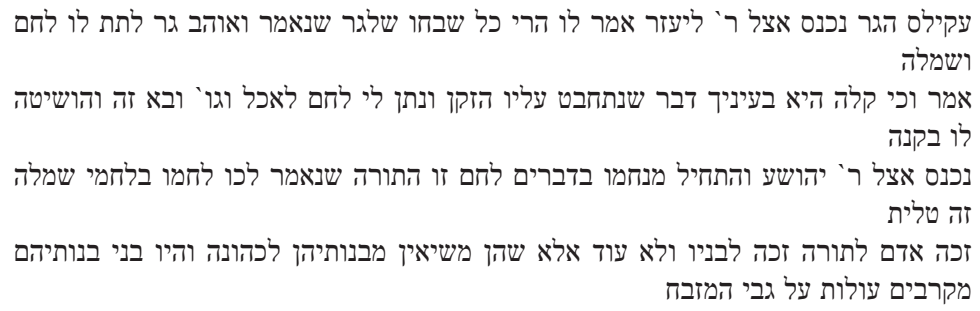

Aquila the proselyte approached R. Eliezer. He (Aquila) said to him: Is this all of a proselyte's gain: "[God] loves the proselyte, providing him bread and raiment" (Deut 10:18)? He (R. Eliezar) said: Is it small matter in your eyes about which the patriarch (Jacob) begged? "And if [God] will give me bread to eat [and clothing to wear]" (Gen 28:20). And this one comes and [God] hands it to him with a reed! He approached R. Joshua, who began comforting him with words: "Bread" refers to the Torah, as it is said, "Go and eat of my bread" (Prov 9:5); "clothing" refers to tālit. When a person obtains Torah, he obtains it for his children; and further, that person's daughters may marry priests, and their children's children sacrifice burnt offerings upon the altar. ${ }^{12}$

${ }^{9}$ Ibid., 366.

${ }^{10}$ Ibid., 369.

${ }^{11}$ Ibid., 379. Labendz seems to have missed at least one important and interesting example of Aquila's authoritative status. In Gen. Rab. 1.12, Rabbi Judah (no less) repeats a similitude in the name of Aquila, which defends the order of the Hebrew wording of Gen 1:1 (בראשית ברא אלהים). Arguably, this instance is of special significance within the tradition surrounding the altered text produced for Ptolemy (אלהים ברא בראשית). On the 13 "Ptolemaic changes," see Abraham Wasserstein and David Wasserstein, The Legend of the Septuagint (Cambridge, UK: Cambridge University Press, 2006) 84-94.

${ }^{12}$ Gen. Rab. 70.5. I cite the text according to MS Vat. Ebr. 30. See also text and notes in Midrash Bereshit Rabbah (ed. J. Theodor and Ch. Albeck; 3 vols.; Jerusalem: Shalem, 1996) 2:802. 
תני רבן שמעון בן גמליאל אומר אף בספרים לא התירו שיכתבו אלא יוונית

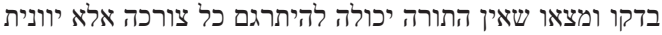

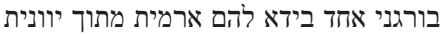

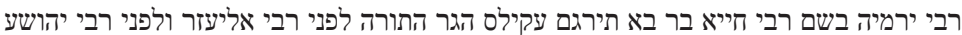

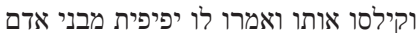

It is taught: Rabban Shimon ben Gamliel says: Scripture was only permitted to be written in Greek. They investigated and found the Torah is able to be sufficiently translated only into Greek. A barbarian "took out" for them the Aramaic from the Greek. R. Yirmiyah in the name of R. Hiyya bar Ba: Aquila the proselyte translated the Torah before R. Eliezer and R. Joshua, and they praised him, saying to him "You are fairer than the children of men" (Ps 45:3). ${ }^{13}$

This symbolic double approbation accords with what we should expect. Broadly speaking, the $g \bar{e} r$ was assimilated as a genuine Israelite. ${ }^{14}$ More importantly, it is a basic error to isolate targumic activity from the rabbinic ratio studiorum. ${ }^{15}$ As the oft-quoted tannaitic maxim has it: "Scripture leads to targum, targum leads to mishnah, mishnah leads to talmud." ${ }^{16}$ Steven Fraade has emphasized this point about the proper "target" culture of targums in an attempt to rein in an errant tendency to separate liturgical, "popular" Judaism from the scholastic endeavor of the rabbis. ${ }^{17}$ This is not the precise danger here, since Labendz does appreciate the evident interpretative purpose of Aquila's translations (as of all scriptural translation). ${ }^{18} \mathrm{~A}$ school setting would be difficult to deny. Still, she pushes too hard in her desire to marginalize this translational dimension of study and the security of Aquila's position in the schema. As an act of interpretation, translation was foundational; and it is not too much to imagine that the contribution of Aquila in this domain would be an object of direct interest to rabbinic culture. Whatever the historicity of the account in the Yerushalmi (to which we will return), it is thus overcautious

${ }^{13}$ y. Meg. 1.8, 71a-b.

${ }^{14}$ See e.g., Gary Porton, The Stranger within Your Gates: Converts and Conversion in Rabbinic Literature (Chicago: University of Chicago Press, 1994).

${ }^{15}$ The origin of the various targums is diverse, of course, and remains a matter of great uncertainty. For a recent comprehensive treatment of the issues, see Paul Flesher and Bruce Chilton, The Targums: A Critical Introduction (Waco: Baylor University Press, 2011). Rabbinic influence on the compositional process cannot be dismissed tout court, as is evident from Targum Onkelos, which cites the Mishnah in several places. See also Anthony York, "The Targum in the Synagogue and the School," JSJ 10 (1979) 74-86.

${ }^{16}$ Sifre Deuteronomy $\$ 161$.

${ }^{17}$ Steven Fraade, "Locating Targum in the Textual Polysystem of Rabbinic Pedagogy," BIOSCS 39 (2006) 71-84. In this connection, the persistent assumption that use of the Hebrew language died within popular culture must be challenged. See, e.g., the evidence of recent philological research offered by Steven Fassberg, "Which Semitic Language Did Jesus and Other Contemporary Jews Speak?" CBQ 74 (2012) 263-80, especially 275-78. See also, Steven Fraade, "Rabbinic Views on the Practice of Targum, and Multilingualism in the Jewish Galilee of the Third-Sixth Centuries," in The Galilee in Late Antiquity (ed. Lee I. Levine; New York: Jewish Theological Seminary, 1992) 253-86.

${ }^{18}$ Labendz, "Aquila's Bible," 361. 
to insist that "the text does not indicate any wider rabbinic approbation of Aquila's translation than that of R. Eliezer and R. Joshua." ${ }^{19}$ Labendz has rather hastily discounted the singularity of this passage, claiming that "in the Yerushalmi, there are numerous instances of one sage offering a praiseworthy interpretation." ${ }^{20}$ She has failed to note how uniquely crafted this precise passage is, however, cleverly punning both on Aquila's name and on the prophecy of "Japheth in the tents of Shem." Nor has she given consideration to the episode's contextual importance within the tractate, which validates translation of the Torah into Greek.

\section{Aquila's Project}

The scope of Aquila's project should here be brought into consideration as a further challenge to the minimalist view. The question has direct bearing on the issue of rabbinic endorsement, not because we must posit a narrow policing instinct among the rabbis (especially in this primitive period), but because the potential magnitude of Aquila's undertaking is hard to explain apart from some underwriting authority. On Labendz's model, we are asked to imagine a translation project sufficiently minimal that there is little need for any form of sponsorship. If this is possible in principle, the foundational problem is the evidence: "Aquila the proselyte translated the Torah." 21 The fragments of Aquila that we possess give every indication that he produced a comprehensive written translation and was not simply an ad hoc oral performer. The patristic witness bears this out in a striking way, for not only do we find a consistent belief that Aquila composed a continuous, written text (along with claims to know it directly) - hundreds of scraps of this text have come down from different parts of scripture. ${ }^{22}$

Jewish and Christian witnesses must at some point confront each other, and the methodological skepticism of sequestering patristic testimony here exposes Labendz to a flawed line of reasoning. There can be no real doubt that a full-scale written translation was attributed to Aquila. Accordingly, we are forced to ask the likelihood of such a thing independent of rabbinic involvement. ${ }^{23}$ Bracketing the material questions of financial backing and access to scrolls, the legendary scale

${ }^{19}$ Ibid., 359

${ }^{20}$ Ibid.

${ }^{21}$ y. Meg. 1.8, 71a-b.

${ }^{22}$ On the sources for fragments of Aquila see Kyösti Hyvärinen, Die Übersetzung von Aquila (CB OTS 10; Lund: Gleerup, 1977) 12-13; and Field, Originis Hexaplorum, I-II. Aquila evidently translated the whole Hebrew Bible. The limitation to the Torah in y. Megillah should be understood for its specific theological and liturgical significance.

${ }^{23}$ If the scope of Aquila's project distinguishes it significantly from earlier ad hoc recensional activity, Barthélemy's basic instinct is sound to associate even the minor recensions with the rabbinic school of Hillel. See Barthélemy, Les devanciers, 144-57. Abraham Geiger (Jüdische Zeitschrift für Wissenschaft und Leben 1 [1862] 62-64) argued that Symmachus the translator should be identified with the Tannaitic Sumcos (סומכוס), a disciple of Rabbi Meir; and recent scholarship accepts this. See Natalio Fernández Marcos, The Septuagint in Context (Boston: Brill, 2007) 125-26. 
of royal (not to say divine) patronage legitimating the LXX would alone make it surprising to find a freelance translator in the ancient world challenging the status of this translation (see Let. Aris. 312-7; Justin, Dial. 71.1-4). ${ }^{24}$ To appreciate the point, Josephus - who in the Jewish Antiquities "translated the Hebrew scriptures"

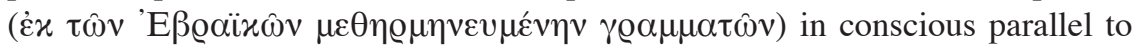
the Seventy under King Ptolemy (Ant. 1.5; cf. 1.10-12, 17)- had no less than the Flavian dynasty behind him..$^{25}$

If simply from the religious and cultural perspective, then, some social backing of Aquila's project seems required, it may be countered that the rabbinic movement in the early third century was in no position to sanction the undertaking in a meaningful way. ${ }^{26}$ Admittedly, this objection underscores a genuine contingency in the argument, but here the risk of reductionist minimalism must be faced directly. While it is right to chasten the extravagant retrojection of rabbinic influence and insist upon sobriety in assessing the role of the sages and neśi'im, revisionist reconstructions of the period that erase all effective rabbinic authority inevitably proceed on arguments from silence. ${ }^{27}$ Given the very early date here in view, of course, it will be necessary to imagine some formative coalition of authorizing parties. The aegis of "rabbinic" patronage could have shared status with displaced (Hellenized) priestly sectors, for instance. At some point, nonetheless, it is clear

${ }^{24}$ The Letter of Aristeas recounts the stories of Theopompus and Theodectus, who were smitten by God for quoting from the LXX in inaccurate or misleading ways.

${ }^{25}$ The circumstances of Josephus under Domitian at the time of the publication of the Antiquitates are not as certain as his favored status with Vespasian and Titus when the Bellum was produced. Nonetheless, as Gregory Sterling (Historiography and Self-Definition: Josephus, Luke-Acts and Apologetic Historiography [NovTSup 64; Atlanta: SBL, 1992] 235) concludes, "it is sufficient to note that the Antiquitates was written in Rome in association with the highest literary circles of the empire."

${ }^{26}$ The thesis of an inflated rabbinic narrative, claiming more authority and influence than is accurate, has gained much ground in the last decades. The perspective was pioneered by Erwin Goodenough, Jewish Symbols in the Greco-Roman Period (13 vols.; Princeton: Princeton University Press, 1953-1968), and was greatly buttressed by Neusner's work in the 1970s and 1980s. The most important recent expression of this "minimalism" (his term) is Seth Schwartz, Imperialism and Jewish Society, 200 BCE to 640 CE (Princeton: Princeton University Press, 2001). See also Martin Goodman, "The Roman State and the Jewish Patriarch in the Third Century," in The Galilee in Late Antiquity (ed. Levine), 107-19; Shaye J. D. Cohen, "The Rabbi in Second Century Jewish Society," in Early Roman Period (ed. W. Horbury, W.D. Davies, J. Sturdy; vol. 3 of The Cambridge History of Judaism; New York: Cambridge University Press, 1999) 922-90; and Catherine Hezser, The Social Structure of the Rabbinic Movement in Roman Palestine (Texte und Studien zum antiken Judentum 66; Tübingen: Mohr Siebeck, 1997).

${ }^{27}$ For a strong statement of the difficulties in Schwartz's presentation, see Yaron Eliav, "The Matrix of Ancient Judaism: Imperialism and Jewish Society, 200 BCE to 640 CE," Prooftexts 24 (2004) 116-28. See also Michael Satlow, “A History of the Jews or Judaism? On Seth Schwartz's Imperialism and Jewish Society, 200 BCE to 640 CE," JQR 95 (2005) 151-62. On the flawed thesis of a shattering religious tragedy in post-70 Judaism, see also Jonathan Klawans, Josephus and the Theologies of Ancient Judaism (New York: Oxford University Press, 2012). 
that Aquila's comprehensive translation was integrated into the rabbinic sphere, and the safest explanation is that his work was sponsored there in some form from the start..$^{28}$

If the rabbinic sources restrict usage of this translation to cases of more problematic texts, this limited engagement simply suits their selective purpose and is only to be expected. Here, once more, the method of Labendz is misleading, for she has constructed an unfortunate comparison. In particular, Jerome also uses Aquila in exactly the same highly "atomistic" fashion (Aquila transtulit \|tirgēm 'aqilas): there is nothing peculiarly rabbinic in such employment. Commenting on Qoh 1:5, for instance, Jerome remarks: "The Hebrew has soeph, which is rendered by Aquila as عiojveî, namely aspirat. Symmachus and Theodotion, however, have recurrit, since the sun returns to its place." ${ }^{29}$ Such a pattern of lexicographical appeal, repeated countless times, sheds significant light on the rabbis' own usage. Accordingly, instead of comparing apples and oranges, namely rabbinic exegesis with the biographical comments of the church fathers, it is more fruitful to compare rabbinic and patristic exegesis.

It is clear, moreover, that a full written translation and a derivative "dictionary" usage are not mutually exclusive options. Indeed, given the unlikely event that a complete and cumbersome collection of Aquila's scrolls would have been widely disseminated, a collation of helpful glosses would be a perfectly natural development..$^{30}$ It is imaginable, for instance, that Aquila's work would have been

${ }^{28}$ Endorsement of Greek translations was resisted in certain quarters among the Tannaim (e.g., t. Meg. 3.41) but evidently too established to eradicate. Accordingly, extant translations were revised and progressively brought under control. The critical point is to recognize the early date of this debate (see y. Meg. 71c). See Willem F. Smelik, "The Rabbinic Reception of Early Bible Translations as Holy Writings and Oral Torah," JAB 1 (1999) 249-72. While recognizing diverse opinions, Smelik concentrates on how rabbis promoted the targums as a promulgation of the Oral Torah. This movement sheds important light on Aquila and the other revisers of the LXX.

${ }^{29}$ Jerome's citations of Aquila's glosses and variants are too numerous to register in full. Very frequently, the citations are paired with readings from Symmachus and Theodotion. Typical is his Commentarius in Ecclesiastin ad Paulam et Eustochium (PL 23, cols. 383-498), which cites Aquila 17 times, and the Commentarius in Isaiam prophetam libri doudeviginti (PL 24) which cites him well over 100 times. The example above (PL 23, col. 387) is chosen entirely at random.

${ }^{30}$ There is in fact evidence of this secondary usage. An interesting manuscript fragment of medieval date and unknown provenance, recording Hebrew lemmata paired with Aquila's Greek glosses (in Hebrew transcription), was found among the Cambridge University Library collection from the Cairo Genizah. See N. R. M. De Lange, "Some New Fragments of Aquila on Malachi and Job?" VT 30 (1980) 291-94; and Greek Jewish Texts from the Cairo Genizah (Texte und Studien zum Antiken Judentum 51; Tübingen: Mohr-Siebeck, 1996). As is evident from so many of the genizah finds, the medieval date of the fragment is not decisive for the dating of the text. For the evidence of medieval reception of Aquila's recension among Greek speaking Jews, see De Lange, "Jewish Transmission of Greek Bible Versions," in XIII Congress of the IOSCS: Ljubljana, 2007 (Atlanta: SBL, 2008) 110-17. The reception of Aquila is also implicated in the controversial question of Justinian's novella of 553. See the bibliography in Amnon Linder, The Jews in Roman Imperial Legislation (Detroit: Wayne State University Press, 1987) 411. See additionally Jerome on Ezek 3:5 and Augustine, Civ. Dei, 15.23. 
known in a form comparable to the etymological compendia found in Hellenistic contexts. ${ }^{31}$ Regardless of the secondary form of acquaintance, however, at some stage we must account for a mining of textual glosses from the complete edition; and such activity again suggests (though it certainly does not prove) that the underlying translation itself enjoyed some rabbinic imprimatur.

Beyond the isolated pattern of usage, a further objection can also be addressed. Labendz contends that the imperfect alignment of the rabbis' citations of Aquila with our extant evidence compels us "to rule out the rabbis possessing a written text of the translation" and to opt instead for oral tradition. ${ }^{32}$ The problem itself is likely overstated.$^{33}$ In any event, Labendz wisely qualifies her claim in a footnote with the comment "unless there were different recensions"- yet she makes no mention of Jerome's explicit witness to "[Aquilae] secundam editionem quam Hebraei $x \alpha \tau$ '

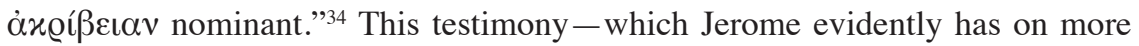
than hearsay, since he quotes from both editions - warrants real attention and could be a critical missing element in the reconstruction of Aquila's project. Indeed, the revealing name of the revision offers leverage in sifting through the citations of Aquila and provides a point of reference to evaluate the rabbis' distinctive engagement with Aquila. Frederick Field's description is succinct:

The theory is that Aquila produced two translations of the whole of Sacred Scripture. The first was fairly free, in which he strove aptly to translate the sense rather than single words. The other was that which they call $x \alpha \tau$ ' $\dot{\alpha} x \varrho i ́ \beta \varepsilon \iota \alpha v$, to which alone belonged the fault of servility and excessive lack of curiosity which is indelibly linked with his name. ${ }^{35}$

If this portrayal risks perpetuating "the persistent stereotype" lamented by Rajak (proselytes et contensiosus interpres), ${ }^{36}$ the classical characterization of Aquila's strained one-to-one literalism should not be pressed too hard. As the study of Kyösti Hyvärinen has labored to show, there is more syntactical sensitivity in

${ }^{31}$ See Rudolph Pfeiffer, History of Classical Scholarship from the Beginnings to the End of the Hellenistic Age (Oxford: Clarendon, 1968). Pfeiffer's landmark study chronicles the emergence of philological scholarship in Alexandria.

${ }^{32}$ Labendz, “Aquila's Bible," 366.

${ }^{33}$ Certainly, the vagaries of transmission have compromised an already incomplete body of evidence (e.g., עקסיוס for ischyros in Gen. Rab. 46.1; see Veltri, Libraries, Translations, and 'Canonic' Texts, 177).

${ }^{34}$ See e.g., Jerome, PL 25. The second edition is also mentioned by Epiphanius (PG 43, 261-64). See James E. Dean, Epiphanius' Treatise on Weights and Measures: The Syriac Version (Chicago: University of Chicago Press, 1935) 32. On the second edition see Field, Originis Hexaplorum I, xxiv-xxvii. Field enumerates 77 cases where Jerome provides parallel readings from the two editions.

${ }^{35}$ Norton, Field's Prolegomena, 52. "Duas autem totius S. Scripturae versions eum edidisse, primam liberiorem, in qua sensum potius quam singulas voces apte reddere studebat; alteram vero quae $x \alpha \tau$ ' ’’ @í $\beta \varepsilon \iota \alpha v$ nominabitur, ad quam solam pertinebat culpa servilitatis et nimiae curiositatis quae nomini ejus inusta est," Field, Orginis Hexaplorum I, xxv.

${ }^{36}$ Jerome, Ep. LVII ad Pachommiam (PL 22, col. 1252). 
Aquila than has often been thought. ${ }^{37}$ One even finds echoes of Homer and Herodotus. ${ }^{38}$ Nonetheless, Hyvärinen is still quite comfortable speaking of "die starre Wörtlichkeit der Übersetzung," and it is not inappropriate to take this as a provisional description of the kat' akribeian edition. ${ }^{39}$ At the same time, this second "edition" must itself be approached carefully. ${ }^{40}$ Field's own opinion is that Aquila "prepared [only] one single translation of the Bible . . then, because the care for accuracy was naturally instilled in him, he withdrew and reviewed his work." ${ }^{11}$ This process of revision was by all appearances limited in extent, ${ }^{42}$ though it remains difficult to determine just how complete the altered translation may have been. ${ }^{43}$ In any event, Aquila's personal "concern for accuracy" is not the best explanation of the kat' akribeian revision, as the rabbinic literature helps to show.

\section{Citations of Aquila}

An examination of the eleven or twelve extant citations of Aquila in rabbinic literature suggests a real integration of his translation into the midrashic enterprise. Far from supplying the rabbis a narrow dictionary service, Aquila's renderings interact directly with homiletic and scholastic themes. Such interpretative translation, moreover, appears to be linked to Akivan ideology in the second edition.

The rabbinic evidence is predictably limited. By sheer luck, however, one of the few rabbinic citations of Aquila coincides with a case where both editions are attested. ${ }^{44}$ In Lev. Rab. 11.9, Aquila's translation is drawn into a discussion on the meaning of 'almut in Ps 48:15.

${ }^{37}$ Kyösti Hyvärinen, Die Übersetzung von Aquila, 86.

${ }^{38}$ So Field, Originis Hexapla I, xxiii-xxiv; and Barthélemy, Devanciers, 15-21.

${ }^{39}$ On the phenomenon of literalism in ancient translations, see Sebastian Brock, "Aspects of Translation Technique in Antiquity," Greek, Roman, and Byzantine Studies 20 (1979) 68-87; and James Barr, The Typology of Literalism in Ancient Biblical Translations (Göttingen: Vandenhoeck \& Ruprecht, 1979) 8-9.

${ }^{40}$ The modern editors of Schürer (The History of the Jewish People in the Age of Jesus Christ (175 B.C. - 135 A.D) [ed. Fergus Millar, Geza Vermes, and Martin Goodman; 4 vols.; Continuum International, 1973] 3.1:495) accept the second edition as a later version attributed to Aquila "because of his growing prestige."

${ }^{41}$ Norton, Field's Prolegomena, 52. "Aquila igitur, ut nostra fert opinio, unam Bibliorum versionem, eam scilicet cujus indolem et proprietates in praecedentibus descripsimus, concinnavit; deinde, quo ei naturaliter insitum est accurationis studio, opus suum denuo retractavit et recognovit, correctionibus quae necessariae viderentur ad marginem exemplaris, vel, si mavis, editionis, prioris appictis. Utrum vero totum Sacrum Codicem, an libros tantum ejus difficiliores secundis curis subjecerit, deficientibus probationibus pro certo definiri nequit," Field, Originis Hexapla I, xxv.

${ }^{42}$ Humphrey Hody (De Bibliorum Textibus Originalibus, versionibus Graecis, \& Latina Vulgata [Oxford, 1705] 577-78) observes that Jerome never cites the second edition in his commentaries on Isaiah or the minor prophets.

${ }^{43}$ See Field, Originis Hexapla I, xxvii.

${ }^{44}$ Field would have rejected the "really obscure" rabbinic reading outright, were not "an equally perplexing" reading attested in the Syrohexaplaric version. See Field, Originis Hexapla II, 169 n. 37 and Originis Hexapla I, xvii. 


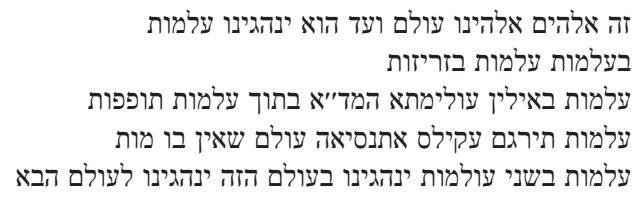

This is our God forever and ever; He will lead us 'almut' (Ps 48:15), in youthfulness ('ulemut); or 'almut means in liveliness.

Or 'almuth means like maidens ('alämot), as it is written, "In the midst of maidens ('alämoth), playing timbrels" (Ps 68:26).

Aquila translated 'almut as athanasia, a world in which there is no death.

Or 'almut means two worlds ('olamot), He will lead us in this world, and he will lead us in the world to come. ${ }^{45}$

It seems likely that Aquila is punning here on ' $a l$ and ' $a l$ to derive the alpha-privative form a-thanasia ('al mut/māwet). ${ }^{46}$ Such playful, phonetic exegesis is obviously enriched by hearing the Hebrew text, and this suggests a targumic interaction with the Vorlage different from that of a freestanding translation like the $\mathrm{LXX}^{47}$

This homophonic play differs from the rendering found in Aquila's alternate (second) edition, preserved in the Syrohexaplaric version and retroverted by Field as kai epi thanaton ananeōsei (anakainisei). ${ }^{48}$ Here the interaction with the Hebrew text is different, at once closer and more distant. On the one hand, we find a very literal "etymological" translation (epi thanaton = "al māwet) of the type famously associated with Aquila and from which the original reading might be easily reconstructed (in a way impractical for the more subtle gloss athanasia). ${ }^{49}$ On the other hand, this analytic, hyper-literal correspondence fits awkwardly with ananēssei, a far from literal rendering of yӗnahagēnu. Whatever the technical reasons for this rendering, the idea of a "renewal" ostensibly links the present

45 Text from Mordecai Margulies, Midrash Wayyiqra Rabbah (5 vols.; New York: Jewish Theological Seminary of America) 1:241-42. Translation adapted from Midrash Rabbah (trans. J. Israelstam and J. Slotki; London: Soncino, 1983) 151.

${ }^{46}$ See Guiseppe Veltri, Gegenwart der Tradition: Studien zur jüdischen Literatur und Kulturgeschichte (JSJSup 69; Leiden: Brill, 2002) 88. Whether the following gloss (עולם שאין בו מות) should be viewed as deriving from Aquila is unclear. It is certainly not a strict rendering of athanasia. It seems most likely that it functions editorially as an explanatory comment and verbal transition to the notion of two contrasting "worlds" ( olamot).

${ }^{47}$ Similar renderings can be found in the Aramaic targums. Targum Isaiah, e.g., renders the geographical reference misela ("from Sela") in Isa 16:1 as if it were a participle of the root $s$ - $l$ - "with a performative mem. As Chilton (Targums, 189) remarks, "The meturgeman's playfulness involves a verbal transformation, and one's enjoyment is enriched by recollecting the Hebrew counterpart of his rendering" [italics added].

${ }^{48}$ See Field, Originis Hexapla I, xxvi. In two other places (i.e., Ps 9:1; 45:1) Aquila translated 'almut as neaniotēs, an otherwise unattested word. For a listing of singularities in Aquila's ample Greek vocabulary, see Reider, Prolegomena, 101-38.

49 The practice of breaking up a pluri-literal into two elements is widespread in Aquila: Job 28:3 (Ps 15:1) is a famous example: șalmāwet = skia thanatou. See Reider, Prolegomena, 22. The same analytic trick was known and practiced by the rabbis. See, e.g., Middah 30 in the Baraita of R. Jose the Galilean. 
translation to the immortality previously suggested in 'al mut/māwet-though this very meaning is also distinctly obscured by the preposition epi, where one would idiomatically prefer meta. The whole tangled gloss thus displays this edition's competing cross-purposes: literalism (implying a new independence from the Hebrew Vorlage) and doctrine (attempting to recover or preserve an insight gained from word play with the original text). Admittedly, three words is precious little to go on, but the pattern of blended literalism and creativity recalls a distinctive feature of targumic practice..$^{50}$

A difference between the two editions thus emerges. The rabbinic citation is collected with a series of interpretations highly sensitive to and interactive with the consonantal text, and Aquila figures comfortably within this punning interpretative framework - even if his pun is lost without knowledge of the underlying Hebrew text. The second edition, by contrast, operates within a more independent context, reduplicating syntactic structures embedded in the Hebrew. At the same time, this second edition inscribes an exegetical perspective derived from the translational exegesis of the first edition.

Aquila's involvement in rabbinic exegesis can be further surmised from the strange translation of Prov 18:21 recorded in Lev. Rab. 33.1.

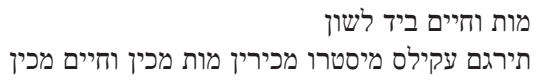

"Death and life are in the power of the tongue" (Prov 18:21).

Aquila translates: spoon of a sword, death on one side, life on the other. ${ }^{51}$

Unfortunately, Aquila's translation of this phrase has not been preserved apart from the rabbinic citation. Nevertheless, two things might be noted. 1) First, given the proverb's perfectly unproblematic vocabulary, it is impossible that a dictionary service should be required here. Indeed, the transliterated Greek words mystron and machairis are more mystifying than helpful. The value of the tradition must, thus, rather be in Aquila's specific midrash. 2) Aquila's peculiar rendering accordingly derives its special force only in conjunction with the Hebrew. The key to the moralizing Greek, after all, is in knowing that the machairis is the "tongue" (lāšon) - a proverbial two-edged sword. How "spoon/spoonful" (mystron) fits with b $\breve{y}$ ad is more obscure..$^{52}$ Perhaps it signifies the "dose" meted out by the sword,

\footnotetext{
${ }^{50}$ The definition proposed by Flesher and Chilton (The Targums, 19-37, at 22) rightly avoids an exclusive literal-dynamic opposition: "A targum is a translation that combines a highly literal rendering of the original text with material added into the translation in a seamless manner." In the present case, "seamless" is perhaps a poor characterization of the translation's total effect.

${ }^{51}$ Text from Margulies, Midrash Wayyiqra Rabbah, 756.

${ }^{52}$ Margulies, who reads מיסטרו as mystron in his notes, glosses the Greek as kaf, which can suggestively mean both "spoon" and "hand" (see Jastrow, s.v.). Unfortunately, the Proverbs text, which plainly reads yad in the sense of "power," does not admit the same ambiguity.
} 
namely life and death. ${ }^{53}$ Again, perhaps the spelling is defective and the underlying Greek is rather mystērion, "secret." 54

However precisely Aquila's cryptic version is explained, the assimilation of such scholastic targumizing into the larger rabbinic project is, in the present case, simple enough to see. The editor of Leviticus Rabbah brings Aquila's imagery forward alongside moralizing maxims and anecdotes, all playing on the topos that the tongue works both good and evil. It would be wrong to find in this homiletic usage a glossary purpose (as might fit the case of Ps 48:15). In the rhetorical context, a better characterization might be an ethical device such as noema. Such homiletic service, in any event, helps broaden our appreciation for the range of interpretative aide Aquila evidently provided-beyond the narrow purpose the minimalized picture of his role imagines.

Aquila's rendering of 'ēl šadday (Gen 17:1) עקסיוס ועיקנוס (Gen. Rab. 46.3) offers another instance of an interpretative rendering, more deeply integrated into the discourse of rabbinic exegesis than might at first be apparent. Ostensibly axios and hikanos, the translation is probably a garbled Hebrew transliteration of ischyros kai hikanos, decipherable through Aquila's wider pattern of rendering these words, preserved elsewhere. ${ }^{55}$ Though the terminological difficulty of ' $\bar{l} l \check{s}$ adday is well known, and it is tempting to see a pure philological interest, it remains hard to see the gloss as presenting any obvious etymological definition or strict translation, at least when compared with the ample modern guesses at the meaning of šadday. ${ }^{56}$ The best solution, rather, seems to be that of Veltri, who has noted that Aquila is probably offering a fusion of the views of Rabbi Eliezer ben Yaakov and Rabbi Natan, which precede him in the Genesis Rabbah passage.$^{57}$ It should be noted in this connection that Eliezer ben Yaakov (T3) was a student of Akiva, while Natan

${ }^{53}$ The Soncino translators envision a "spoon-knife" - apparently a double-sided utensil, with "life" and "death" on the respective ends - but this misses the metaphor of the tongue itself as sword (e.g., Ps 64:4; Prov 12:18; Jer 9:8; Rev 1:16).

${ }^{54}$ Veltri proposes reading mesaiterio machairis ("in the middle point of a sword"), but this does little to illuminate the text (Libraries, Translations, and 'Canonic'Texts, 182). The targum of Proverbs is unusual for its plain dependence on the Syriac Christian Psalter. Possibly, the tradition from Aquila here preserves remnants of a much freer tradition of rendering the book. See J. Weingreen, "Rabbinic Type Commentary in the LXX of Proverbs," in Proceedings of the Sixth World Congress of Jewish Studies (2 vols.; Jerusalem: World Union of Jewish Studies, 1977) 1:407-15.

${ }_{55}$ As Reider (Prolegomena, 152) observes, hikanos invariably renders šadday in Aquila, while 'él is "immutably" translated ischyros. Since Aquila's mechanical correspondence is not obvious at a semantic level, however, it is plausible to assume that the associations derive from the exegesis of this particular Genesis passage. If so, an important principle in Aquila's policy of equivalences becomes clear: binyan 'ab mi-katub 'ehad-based on the exegesis of some particular text, a general translational norm is deduced.

${ }^{56}$ See, e.g., Norman Walker, "New Interpretation of the Divine Name," ZAW 72 (1960) 64-66; and Walter Wiffal, "El Shaddai or El of the Fields," ZAW 92 (1980) 24-32.

${ }^{57}$ Veltri, Libraries, Translations, and 'Canonic' Texts, 177. 
(T4) is linked through Akiva's student Rabbi Meir. Thus, whereas Grabbe sought to undermine the personal association of Aquila and Akiva, there is the distinct suggestion here of some school affinity.

The final citation we will consider brings Aquila's project into direct contact with the figure of Akiva (y. Qidd. 1.1,59a):

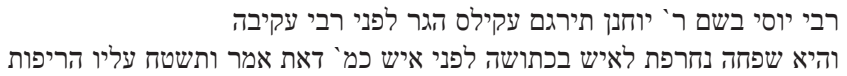

Rabbi Yose said in the name of Rabbi Yohanan: "Aquila the proselyte translated before Rabbi 'Aqiva: 'as she is a slave betrothed to another man' as 'laid by a man' [hence the act of sexual relations has made the owner into her husband, and therefore when he dies she no longer is subject to flogging and the like]. ${ }^{58}$

It is strange that Aquila's rendering appears in Hebrew, though this might be explained in different ways. ${ }^{59}$ For our present purpose, the key fact here is that the suggestive translation of Lev 19:20 follows the teaching of Rabbi Akiva. ${ }^{60}$ Although the use of the views of Rabbis Eliezer and Natan in the preceding example prevents us from regarding this exegetical borrowing as altogether unique, the text here approximates an authoritative attribution-curiously spoken to the source.

Aquila not only adopts Akiva's view, he translates that view "before" (lifnēe him. Accordingly, this episode echoes (however formulaically) the programmatic text we have already seen:

Aquila the proselyte translated the Torah before (lifnēe R. Eliezer and R. Joshua, and they praised him, saying to him "You are fairer than the children of men."

Saul Lieberman would explain this pair of texts on the supposition that Rabbi Eliezer and Rabbi Joshua were "were authorities on Greek language and style," but that Akiva "was not versed in the Greek language to such a degree as to judge the translation as a whole." ${ }^{161}$ In a useful advance beyond Field's proposal, Lieberman posits:

It may be that the original draft, or the first edition of the translation, was confirmed by R. Eliezer and R. Joshua as regards style and exactness, whereas in method and in the translator's corrections in the second edition he was guided by R. Akiba whom he consulted in Hebrew and Aramaic. ${ }^{62}$

\footnotetext{
${ }^{58}$ Translation from Jacob Neusner, The Talmud of the Land of Israel: 26 Qiddushin (Chicago: University of Chicago Press, 1984) 26.

${ }^{59}$ Field (Originis Hexapla, xvii) rejects this reading as "in every way absurd and ridiculous."

${ }^{60}$ See Veltri, Libraries, Translations, and 'Canonic' Texts, 184.

${ }^{61}$ Saul Lieberman, Greek in Jewish Palestine: Studies in the Life and Manners of Jewish Palestine in the II-IV Centuries C.E. (New York: Jewish Theological Seminary of America, 1942) 18-19.

${ }^{62}$ Ibid., 19.
} 
On this view, a text such as we find in $y$. Qiddušin would apparently represent the refinement of an earlier draft already calibrated for "style and exactness" - in short, a kind of adjustment made to the galley proofs. This is probably too sanguine a view of the historicity of these accounts. It is also unclear how (in)competent in Greek Lieberman would have us suppose Akiva to be. An important question is raised, however. Why would an accurate understanding of the Hebrew and Aramaic be the final, rather than the first stage of Aquila's project?

\section{Rabbi Akiva and the Translation of Aquila}

The link between Aquila's translation and Akiva is best understood as expressing a special affinity to the exegetical method and "meritocracy" Akiva came to represent. Such an affinity helps explain a curious feature in Lieberman's theory, which seems to have things backwards. Why would Aquila not treat interpretative problems (i.e. "method" and the meaning of the semitic text) in a preliminary draft and polish the Greek as the final stage of the process? Why, for instance, does one find such idiomatic oddities as kai thanaton ananeōsei in the (presumptive) second edition? One simple answer would be that a well-styled and exact Greek interface was not the ultimate object of that translation made "before" Akiva. If this leads us in the direction of the clumsy Greek of the kat'akribeian text, the example of Ps 48:15 exposes the doctrinal pressure behind Aquila's infelicitous Greek, while in the case of Lev 19:20 we also find Akiva moving Aquila away from a strictly literal rendering of the Hebrew. The best way to address this situation may be to suppose that kat'akribeian should be understood to suggest kat'Akiban (at whatever punning level of association). In other words, "According to the Accurate Sense" functions as a descriptive title for an edition representing the whole Akivan interpretative enterprise - in contrast to the Ishmaelian school. A distinct construction of Hebrew as the lāšon haqodeš ("the holy tongue") is thus implied, entailing a readiness to find meaning in every jot and tittle. ${ }^{63}$ In view of texts like Gen. Rab. 1.14, which contrasts Akiva and Ishmael on just this point, this is a compelling context for understanding Akiva's method.$^{64}$ This characterization would leave room in Aquila's translation for a variety of textual features, beyond simple literalism, allowing us to preserve Lieberman's connection between Akiva and the second edition.

Another factor to consider here is a point Azzan Yadin has recently made concerning Rabbi Akiva. ${ }^{65}$ The haggadic traditions of Akiva's early life, specifically his portrayal as a poor ignoramus, have likely been patterned on a larger rabbinic

${ }^{63}$ On this ideology of the Hebrew language ("verité hyper-hebrä̈que"), see Paul, "La Bible grecque d'Aquila," 235-43. In contrast to Akiva's approach to the text, Ishmael claimed: "The language of the Torah is like human language" (Sifre Numbers §112). See H. L. Strack and Günter Stemberger, Introduction to the Talmud and Midrash (Minneapolis: Fortress, 1991) 20-22.

64 "The kind of Hebrew that comprised the Torah is precisely the point at issue between Ishmael and Akiba," Alan Segal, Two Powers in Heaven: Early Rabbinic Reports about Christianity and Gnosticism (Leiden: Brill, 1977) 74-83, at 75 n. 5.

${ }^{65}$ See Azzan Yadin, "Rabbi Akiva’s Youth,” JQR 100 (2010) 573-97. 
shift towards a new "ideal" of exegetical meritocracy: in the Amoraic Akiva, midrashic ingenuity and direct scriptural engagement displace academic aristocracy and extra-scriptural halakha. ${ }^{66}$ While Yadin wishes to distinguish this development sharply from Akiva's presentation in Tannaitic sources, it is possible that the status issue is more of a "historical kernel" than Yadin prefers to admit. Regardless, it is worth noting the possibility that the Aquila traditions in the Yerushalmi have been drawn into this larger movement and reflect some sort of scripture versus tradition debate in which Akiva as 'am hä' àreș stood over against the well-pedigreed Rabbis Eliezer and Joshua (see $m$. 'Abot 2.8). ${ }^{67}$ If a master-disciple relationship connected these rabbis, the adversarial relation between the two sides is seen in the dismissive treatment Akiva receives at the hands of the two after thirteen years of study ( $y$. Pesah. 6.3, 33b; cf. y. Naz. 56a):

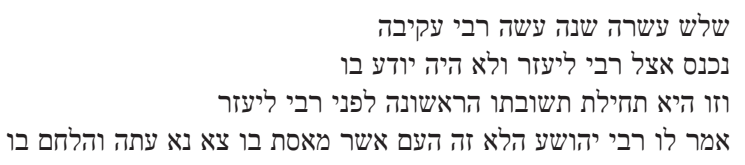

R. Akiba had spent thirteen years. He entered into the presence of Rabbi Eliezer, but the latter did not recognize him. Thus was his first response to Rabbi Eliezer, that Rabbi Joshua said to [Rabbi Eliezer], "Is this not the people you despised? Go out and fight him." (Judg 9:38).

This is a stark contrast with the adoptive legitimacy Eliezer and Joshua had from Johannan ben Zakkai ( $m$. 'Abot 2.8). If a tension is thus to be supposed between Akiva and his teachers, could it be that Aquila's Greek, translated "before" the one and the other, is somehow caught in the middle of these two contrasting "ideals"? The Akivan endorsement would attest Aquila's exegetical merit, whereas the approval of Rabbis Eliezer and Joshua would represent a more tradition-based authority. ${ }^{68}$ If such an opposition likely inflates the significance of the parallel between $y$. Qidd. 59a and y. Meg. 71a-b and overplays the contest between Akiva and Eliezer, it does at least help expose the institutional valence of the latter passage, which Labendz at any rate has missed.

66 Yadin, "Rabbi Akiva's Youth," 596. The extra-scriptural constraints controlling aspects of Tannaitic legislation are exposed in Vered Noam, "Stringency in Qumran: A Reassessment," JSJ 40 (2009) 342-55.

${ }^{67}$ On Akiva's connection to this debate, see Barthelemy, Les devanciers, 9-10.

${ }^{68}$ In other contexts Rabbi Eliezer is openly understood to represent the "semi-sectarian" voice of tradition. See Vered Noam, "Traces of Sectarian Halakha in the Rabbinic World," in Rabbinic Perspectives: Rabbinic Literature and the Dead Sea Scrolls (Leiden: Brill, 2006) 67-85. 
It is striking, in this connection, that in the Babylonian context, Onkelos (the Aquila stand-in ${ }^{69}$ received his targum precisely from the mouth of Eliezer and Joshua, and that these two figures parallel the full prophetic authority behind Jonathan ben Uzziel's targum of the něvi'im (b. Meg. 3a):

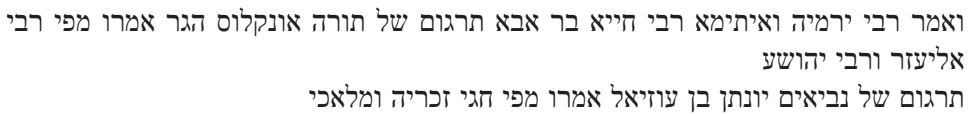

Rabbi Yirmiyah, others say Rabbi Hiyya bar Abba: "The Targum of the Torah was spoken by Onkelos the proselyte from the mouth of Rabbi Eliezer and Rabbi Yehoshua. The targum of the prophets was spoken by Jonathan ben Uzziel from the mouth of Haggai, Zechariah and Malachi."

Jonathan ben Uzziel stands in relation to Haggai, Zecharaiah and Malachi like the men of the Great Synagogue ('Abot R. Nat. 1.16), and Onkelos has a parallel position. Although this sugya develops in a distinct setting (culturally and linguistically) and has its own concerns, it nonetheless supports the idea of the tradents, Eliezer and Joshua, as authorizing Aquila's translation with a secure link to Sinai by means of oral Torah.

However we ultimately seek to explain Aquila's precise connection to Akiva, the witness of $y$. Qiddušin at some level corroborates the basic patristic testimony (which Labendz discards). Whether we have grounds to link Akiva personally with Aquila's second edition as Lieberman suggests, it remains tempting to see the kat' akribeian text as an Akivan product of some sort. Veltri's comment hits the mark: "The question of whether Aquila was really a disciple of the Rabbi is unimportant; much more significant is the conviction that what he translated follows this school, that is: he was a mĕturgĕmān." 70

\section{Aquila's Greek Targum}

The strongly marked rabbinic context of Aquila's work helps explain the trajectory leading from the first to the second edition. The two texts from Leviticus Rabbah suggest that the first edition at least circulated in homiletic circles, where targumizing would have surely been practiced. Aquila's style of translation (occasionally free and occasionally literal) and the interpretative interest seen in the examples considered above also fits well with the shape of other known targums..$^{71}$ It is slender evidence, to be sure, but defends hazarding the claim that

${ }^{69}$ See Veltri, Libraries, Translations, and 'Canonic' Texts, 185-89; Eli Silverstone, Aquila and Onkelos (Manchester: Manchester University Press, 1931); and Leon Leibrich, "Aquila and Onkelos," JQR 27 (1937) 287-91.

${ }^{70}$ Veltri, Libraries, Translations, and 'Canonic'Texts, 175 [italics in original]. Lieberman (Greek in Jewish Palestine, 18) is likewise convinced that "the inner evidence demonstrates the influence of the school of Akiva."

${ }^{71}$ On the range of Targumic interpretation, see Alexander Sperber, The Targum and the Hebrew Bible (vol. 4B of The Bible in Aramaic; Leiden: Brill, 1973) 37-103. 
Aquila began his career in a capacity more or less identical with those peers who produced Aramaic targums of the scriptures. That there would be occasion for a Greek language parallel mĕturgĕmān to those Aramaic counterparts can hardly be doubted, since the Hellenized centers and pockets in Palestine would have been as (or more) needful as other regions and sectors of the population. ${ }^{72}$ True, the patchwork Old Greek version would have been at hand, but in several ways this text would have been undesirable. ${ }^{73}$ Most importantly, it was not composed to work in close tandem with the Hebrew of the proto-Masoretic Text. Thus, divergent text forms (at times wildly divergent) and the impulse to inscribe the midrashic perspectives of oral Torah within the interpretative translation would both have made a rabbinical Greek targum a real desideratum.

This supposition permits us to conceive of a first edition of Aquila in the interlinear form proper to the targum genre. ${ }^{74}$ Two significant consequences follow. First, the raw material for a bi-lingual Wörterbuch would be conveniently prepared. The pattern of "dictionary" usage would thus be facilitated, while a stable base for a subsequent revision would also be set. Second, new attention would inescapably be given to the problem posed by the variant LXX tradition. This would not be a new discovery, of course; but in the process of compiling an interlinear Greek language targum, the issue would necessarily be confronted at a new technical and theoretical level. The work of the ad hoc "correctors"- such devanciers as were behind the Minor Prophets' recension - represents the first open concern for the problem, and these texts would have presumably guided the undertaking of a full-scale Greek targum. Aquila's kat' akribeian text would accordingly be offered as a more considered ideological solution. ${ }^{75}$ While elements of an emergent Jewish-Christian debate might have found some expression in the project (e.g., Isa 7:14; Justin, Dial. 68.8; 71.1; 84.3; cf. also Gen 2:18; Ps 2:2; 27:6; 90:9; Isa 9:5; $49: 5),{ }^{76}$ this dialogue would not be the real generative setting. Instead, it would be the movement towards a deeper engagement with the scriptural text that Akiva came to symbolize.

If this stretches the idea of Field and Lieberman on the scope of the revision and can be little more than very tentative speculation, it at least helps explain several things. First and foremost, how does the contentious, literalistic, "patristic" Aquila

\footnotetext{
${ }^{72}$ Roger Le Déaut, “La Septante, un Targum?” in Études sur le Judaïsme hellénistique (ed. Roger Arnaldez, Raymond Kuntzmann, and Jacques Schlosser; Lectio divina 119; Paris: Cerf, 1984) 149-95.

${ }^{73}$ R. Timothy McLay, "Recension and Revision: Speaking the Same Language with Special Attention to Lucian and Kaige," in XIII Congress of the IOSCS, 293-304.

${ }^{74}$ On this format, see Fraade, "Rabbinic Views on the Practice of Targum," 265 n. 31.

75 See Paul, "La Bible grec d'Aquila" 227, 244-45. Paul has mounted a convincing case for the basic "sacred tongue" ideological background to Aquila's translation. This is no argument against an Akivan affinity or influence, however.

${ }^{76}$ See Field, Originis Hexapla I, xix-xx. After considering the patristic charges of Aquila's anti-Christian tampering, Field concludes that "he [Aquila] did not escape some excess of zeal ...

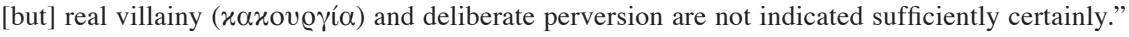


relate to the broader context of Jewish targums? In brief, the suggestion would be that at origin his activity was a simple product of the larger movement, but with this distinguishing feature: Aquila worked in Greek and thus faced a uniquely complex set of textual circumstances occasioned by the LXX tradition. From this context a new project was born with the aim of systematically renegotiating the Greek scriptures' relation to the Hebrew in a way which favored the rabbis' midrashic project - and more specifically the exegesis of the text-sensitive Akivan enterprise. Indeed, for a school convinced that "mountains of halakha" were encoded in every calligraphic flourish of the sacred text, the transposition of the Torah into a foreign script and tongue inevitably entailed a major exegetical trauma, a grave loss of inscribed halakhic data. ${ }^{77}$ How were Hebrew word plays to be accessed? What would become of letter-based gematria? Could interpretative tactics based on the scriptural resonance of key repeated words somehow be preserved? A host of such questions might be posed. The response of the Akivan school was an ideological fiction: a free standing Greek text, no longer fixed to an interlinear format, yet supposedly reduplicating and embedding an Akivan exegesis of the Hebrew. The kat' akribeian text thus offered a more reliable guide to the "meaning" of the sacred scriptures than the problematic LXX.

The proposal is difficult to establish for a simple lack of evidence. If it is admittedly a little too convenient to partition "Aquila" in this way - as a common mĕturgĕmān in the first edition and LXX reviser in the kat' akribeian-there is at least an intelligible progression that moves from one activity to the next. This need not be read as biography either. The "historical" Aquila may well have bequeathed a traditional enough Greek targum to the school of Akiva, which was then somehow corporately responsible for the revised edition. At the same time, Aquila may have already been heir to a school tradition, represented in the scrolls from Nahal Hever. Indeed, as the characteristic kaige literalism is reproduced by Aquila, this could indicate an earlier origin for similar textual features as well - even the celebrated "slavishness" of his nota accusativa. In Gen. Rab. 1:14, after all, Rabbi Ishmael attributes the inclusive sense of 'et (among other things) to Nahum of Gam-Zu, Akiva's master. In a word, then, Aquila would stand at the center of a long process of textual reconfiguring, accruing to himself a certain measure of the work of the whole school. ${ }^{78}$ The fact that the proselyte has become a little larger than life would support such a development. Indeed, this tendency to attribute translation traditions to "Aquila" can be seen if we consider his dominant role as the targumist of Palestine.

${ }^{77}$ See m. Meg. 1.8; m. Yad. 4.5; also b. Meg. 8b-9a. and y. Meg. 83a.

${ }^{78}$ Of the texts considered above, Field (Originis Hexapla I, xvii) doubts the authenticity of both Prov 18:21 and Lev 19:20 as genuine citations of Aquila and finds only four of the rabbinic citations entirely credible. 


\section{Aquila the Palestinian Měturgĕmān}

The literary persona of Aquila grew along a similar trajectory as his translation. Thus, within the Palestinian context, Aquila holds a unique position. He is effectively the only mĕturgĕmān character. While this leaves little material for direct comparison, it suggests the representative significance Aquila holds as the personification of targumic activity. Accordingly, it supports the proposal that his translation was well integrated into the wider targumic milieu-even to the point of metonymy. "Aquila" clearly bore an eponymous significance.

Aquila's translations are always introduced with a peculiar formula: tirgēm 'aqilas. The odd preference for this language can be felt in a passage from Eicah Rabbah 1.1:

$$
\text { ואלבישך רקמה רבי סימיי אמר פורפירא תרגם עקילס אפליקתא }
$$

I clothed you also with richly woven work (Ezek 16:10). Rabbi Simai said: "in purple garments." Aquila translated: "embroidered garments."79

Why does Rabbi Simai simply "say" ('āmar) while Aquila "translates" (tirgēm)? Both offer Greek interpretations. We may reasonably presume that it means to assign to Aquila some official or honorific status as mĕturgĕmān. In this case, however, we need to account for the extension of this same language to many other figures, for example Rabbi Jacob of Kefer Naburaya, a marginal fraternizer with Christians, who also "translates" (y. Ber. 9.1, 12d):

$$
\text { תמרגם יעקב כפר נברייא בצור לך דומיה תמה כלילה אלהים ביה בציון סמא דכולא משתוקא }
$$

R. Jacob of the village of Naburaya in Tyre translated "Praise is due to thee O God, in Zion" (Ps. 65:1): "Silence sums it all up." As regarding a priceless pearl, all who attempt to praise it, [by so doing merely] diminish its value. ${ }^{80}$

This particular example gives occasion to note the imprecise semantic range of tirgēm, since Rabbi Jacob's word play and tiny parable are an "interpretation" of the verse and not really a "translation." Such ambiguity can be sorted out, however, and the particularity of Aquila is clear. As Labendz notes: "The introduction, 'so-and-so translated' to a translation-interpretation is used in rabbinic literature many times, but Aquila is unique in that his translations are never introduced by a different verb (אמר, דרש, etc.) and in that these translations are his only contribution to rabbinic literature." ${ }^{81}$ Ultimately, then, it is the consistent and exclusive employment of the tirgèm language in connection with Aquila that is the relevant phenomenon, not

79 Translation adapted from Deuteronomy and Lamentations Rabbah (trans. J. Rabinowitz and A. Cohen; London: Soncino, 1983) 67.

${ }^{80}$ Translation adapted from Tzvee Zahavy, The Talmud of the Land of Israel: 1 Berakhot (Chicago: University of Chicago Press, 1984) 307.

${ }^{81}$ Labendz, "Aquila's Bible," 367 [italics in original]. The exception of Gen. Rab. 1.12 has already been noted above (n. 11). 
the word by itself. Although Labendz hesitates, this pattern seems best explained if Aquila was simply identified in a direct and personal way with the professional activity of the měturgermān. ${ }^{82}$ The language does not "reflect his second-class status." 83

The tight association of Aquila with tirgēm language is a more lionizing development than Labendz appreciates. Aquila's personality as "the translator" in the Palestinian corpus appears to the detriment of possible peers. Onkelos's counterpart in the Bavli, Jonathan ben Uzziel, notably, appears only once in the Yerushalmi (y. Ned. 5.6):

שמונים זוג של תלמידים היו לו להלל הזקן גדול שבהן יונתן בן עוזיאל והקטן שבהן רבן

יוחנן בן זכאי זוגי

Hillel the Elder had eighty pairs of disciples. The oldest of them was Yonatan ben Uzziel. The youngest of them was Rabban Yohanan ben Zakkai.

In this case, Jonathan is quite incidental. He does not translate, nor is he associated with the targum of the prophets. His purpose is simply to be a foil for Hillel's praise of the youngest (whereas the Bavli parallel in b. Sukkah 28a has reasserted Jonathan's preeminence as the greatest).

The singularity of Aquila's characterization as the exclusive měturgĕmān likely owes as much to his special status as a proselyte and haggadic hero (e.g. y. Hag. $2.1,77$ a) as it does to anything peculiar about his activity. We should hesitate then to conclude that the formulaic tirgēm distinguishes Aquila's translation in any way from larger targumic culture and practice. Indeed, it is quite possible that the magnitude of Aquila's persona has attracted translation traditions which did not originally belong to him and that he has in this way become the very emblem of targumic activity. This would explain the curious appearance of Aramaic translations in the Aquila traditions. The example in Qoh. Rab. 11.3 is instructive:

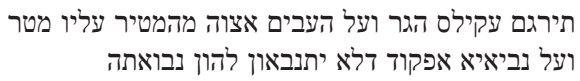

Aquila the proselyte translates "I will also command the clouds that they rain no rain upon it" (Isa 5:6) by "I will also command the prophets not to prophesy prophecies for them." ${ }^{\prime 4}$

Whereas the Aramaic of $y$. Qiddushin 1.1 might be explained as the language of the tradents (either Rabbi Yose or Rabbi Yohanan), here the case is different. If we associate a translation such as this one of Isa 5:6 with the traditions behind Targum Jonathan - and there is a real thematic affinity (cf. Isa 40:1-2) - then perhaps Aquila has, by sheer force of personality, occupied the space later cleared

${ }^{82}$ Ibid.

83 Ibid.

${ }^{84}$ Translation from Midrash Rabbah: Ruth Ecclesiastes (trans. L. Rabinowitz; London: Soncino, 1939) 292. 
for Jonathan ben Uzziel ${ }^{85}$ Obviously, many anonymous translations still appear in the Palestinian literature, but named attributions cluster around Aquila. In the Palestinian context, then, "Aquila translated" would be a formal structure that has overgrown its original application to the proselyte. If Jonathan ben Uzziel ultimately emerged as a mystic and mĕturgĕmān in his own right in the context of the Bavli, Onkelos would nonetheless be the most overt expression of this earlier Palestinian tendency to identify all targumic activity (even Aramaic) with the work of Aquila.

\section{Conclusion}

The status of Aquila in rabbinic literature is more elevated than a minimalistic revision of the evidence suggests. Rather than being a peripheral functionary, Aquila's exclusive role as the representative Palestinian mĕturgĕmān accredits his project with an integral significance, and his importance finds expression in various ways within the rabbinic tradition. Of special interest is the prospect that the proselyte has become a center of gravity for diverse translation traditions. If we are willing to extend this characterization and imagine an Aquilan kat'akribeian text worked on by the Akivan school, it may be possible to respect Grabbe's warning of linking "a particular translation with a particular figure of Jewish literature," yet preserve something of the traditional picture. It is enough to take a "historical kernel" view. The testimony of Jerome could be taken at face value-so long as "Akiva" and "Aquila" are read as the Amoraic constructions they surely were by his time: Akibas, quem magistrum Aquilae proseliti autumant ${ }^{86}$ Ultimately, Barthélemy's contextualization remains quite convincing, however tainted by pre-Neusnerian naiveté about the simple historicity of rabbinic traditions. Clearly "Aquila" belongs to the movement of Greek recensions, and though his translations lack full consistency (as Grabbe has shown) and bear the influence of different brands of exegesis, a core connection to Akivan principles is indisputable. The effort to situate "Aquila" more precisely in the rabbinic movement thus demands greater imagination about a complex textual history - not a skeptical withdrawal from uncertainties or the burden of educated guesswork.

${ }^{85}$ In the view of Barthélemy (Les devanciers, 144-57), the confusion of Greek revisers and Aramaic targumists has also touched Jonathan ben Uzziel, who should be identified with Theodotion.

${ }^{86}$ Commentarium in Isaiam 8.11 (CCSL 77). 